\title{
REFLECTIONS ON THE EDUCATIONAL DISPUTES IN CHINESE UNIVERSITIES AND THE CONSTRUCTION OF HARMONIOUS EDUCATIONAL RELATIONS
}

\author{
XiangYu ${ }^{1^{*}}$, Shengming Yang ${ }^{2}$ and Yuyin Huang ${ }^{3}$ \\ ${ }^{1}$ Dr, Fujian Jiangxia University, China, upcyuxiang@gmail.com \\ ${ }^{2}$ Assist. Prof., Fujian Jiangxia University, China \\ ${ }^{3}$ Assist. Prof. Dr., Ningbo Open University, China \\ ${ }^{*}$ Corresponding Author
}

\begin{abstract}
With the gradual popularization of higher education, more and more young people have access to educational opportunities, but the education disputes between colleges and students have increased, the most intense conflict and the highest social concern cases were happened from students which have been punished by colleges for cheating in exams. This type of case reflects the differences and oppositions in the education legal system, and also reminds the importance and urgency of establishing a harmonious educational relationship. This article reviewed several cases of education disputes that had a greater impact, and analyzed the legal issues in them, with a view to standardizing educational activities and building a harmonious educational relationship
\end{abstract}

Keywords: degree, lawsuit, university.

\section{INTRODUCTION}

In 1998, Tian Yong v. Beijing University of Science and Technology refused to issue degree certificate administrative lawsuit. It was a well-known case in which a student sued the school and was included in the Supreme People's Court. The plaintiff Tian Yong was sentenced to "capital punishment" by the school for violating disciplines during the exam, the university ordered him to drop out and cancel his school status. However, it happened a mistake that Tian Yong continued to complete his studies under the eyes of the school. He was told that he did not have a student status until he graduated, and he would not be issued degree certificate. Tian Yong was angry and took the school to court. The Haidian District Court of Beijing determined that the case was within the scope of administrative litigation and that the defendant was qualified as an administrative subject. Although the defendant made a decision to withdraw from the plaintiff, it did not have legal effect due to the defendant's negligence and procedural defects. The internal documents on which the defendant punishes the plaintiff are also in conflict with relevant state regulations and should be invalid. The administrative act performed by the defendant was illegal, so the defendant was sentenced to issue a graduation certificate to the plaintiff, perform graduation dispatch procedures consistent with other graduates, and give the plaintiff the opportunity to apply for a degree.

Five years later, in 2003, the Intermediate People's Court of Nanchang City, Jiangxi Province also tried an administrative case in which a graduate of Nanchang University sued his alma mater for not granting his degree. The CCTV report also attracted widespread attention and sparked a social discussion. Xiao Yu, a student of Nanchang University, was once punished with withdrawal for helping others to take the exam, but the school subsequently granted him a leniency and allowed him to resume school and allowed Xiao Yu to 
graduate normally, but refused to grant Xiao Yu a bachelor's degree. The school's explanation was that Xiao Yu's course grades passed, but he cheated in the exam, and in terms of "morality", he did not meet the requirements of the teaching plan. Therefore, the school degree committee did not issue a degree certificate to him in accordance with the school's degree award method. He also pointed out that this is also the spirit of the Ministry of Education's "Emergency Notice on Adopting Effective and Effective Measures to Resolutely Stop the Unhealthy Trend of Cheating in Colleges and Universities". But Xiao Yu believed that in the "Regulations on Degrees of the People's Republic of China", there was no provision that students cheating in exams can cancel bachelor's degrees. The school's approach was too strict and did not have sufficient legal basis. On September 15, 2003, Xiao Yu filed an administrative lawsuit with Nanchang Intermediate People's Court, requesting the court to order Nanchang University to grant a bachelor's degree and issue a degree certificate. The court held that although the Education Law and the State Council's Bachelor's Degree Awarding Regulations did not clearly stipulate that such conduct would not be granted a bachelor's degree. However, the Education Law and Degree Regulations also grant schools the right to formulate school rules and school discipline management. Xiao Yu violated school discipline and school rules and the school did not grant him a degree, which was a manifestation of the school's educational autonomy. The judiciary cannot interfere with the educational autonomy of schools. The judgment dismissed the plaintiff's claim.

\section{LEGAL ANALYSIS OF EDUCATIONAL DISPUTES}

The above two cases basically represent the current handling methods and results of such educational disputes. Similar cases have occurred frequently in recent years, and the responses of the government, academia, and society are different. Therefore, we still need to distinguish between the school and the students involved in the legal theory.

At present, most scholars interpret educational disputes from different fields of administrative law and administrative procedure law. For example, Professor Shen Kuijing asked whether schools authorized by laws and regulations belong to administrative entities, and whether school management rights and degreegranting rights are administrative powers. Questions were raised; Professor Ma Huaide analyzed the administrative litigation using the special power relationship of administrative law and the theory of public service legal persons; Dr. He Haibo used the principle of due process and the principle of trust protection to create momentum for the plaintiff, and affirmed that this was the development of law. Other articles express the views of protecting citizens' right to education, and the view that judicial trials actively respond to the needs of rights. In addition to these disputes, the researchers also turned to the effectiveness of school management and related legal adjustments, and discussed the balance of rights and obligations between the school and students, reflecting the level of humanistic care.

We believe that there are problems of the same nature in such disputes---examination violations and school status and degree systems, and the deep-seated relationship lies in how to locate the relationship between the education authority, school, and students.

First, the "Education Law" stipulates that "the school shall manage the student status of the educated, and implement rewards or punishments." So the act of defendant school's handling of the plaintiff's withdrawal from school was an administrative act? There is a theory of special power relations in traditional German law. It is believed that the management relationship of public schools to students is a special power relationship. The rights and obligations of both parties are not equal, and the counterparty under management does not have the right to litigate. The current view has changed again, and the litigation right of the counterpart is gradually recognized ( $L u$ F,Li QR, 2005, pp-345-360). China has not introduced this theory, and we usually talk about administrative sanctions or internal administrative acts, which are different from external and specific administrative acts. China's Administrative Litigation Law has no regulations in this area.

Second, the fuse of this type of case is that colleges and universities will dismiss students who violate the discipline of examinations and deprive them of their school status. What is the student status? The theory of modern politics and administration believes that the school is a public sector that provides non-monopoly public products-education services. The relationship between schools and students is different from that between employees and employers, and that between civil servants and administrative agencies (Hosokawa, $\mathrm{S}, 1978, \mathrm{pp} 71-92)$. The relationship is also different from the relationship between the administrative subject and the management counterpart, but closer to the relationship between consumers and service providers. In the past "unit society" environment, the education authority and the school had an administrative subordination relationship. Students were personally dependent on the school. The right to education was also a shortage and privileged qualification. Students were placed under the management of the education department to conduct personal restraint and behavior control. They relied on the means of student status, distribution, and dispatch. However, there was no reason to understand the student status system as a 
manifestation of national administrative power (education management power). It can only be said that China attached it to administrative functions (Juan David Piñeres 2011, pp11-23). The school registration system is very obvious. Although it seems to be just a student's qualification to attend a school, it carries many nonlegal obligations. Because it is recognized by the so-called education administration department, if a student is deprived of the school, his student status is equivalent to being expelled by the entire education system, which also means that it is denied by the education authority and will be subject to all kinds of discrimination in the society. Therefore, the student registration system is somewhat similar to the household registration system, which has great incompatibility.

Third, this kind of cases all involve the school's autonomy, but it is questionable whether this "autonomy" of the school is the administrative discretion or the management power of the internal affairs of the industry organization? If it is administrative discretion, not even the court can interfere. However, the macro basis for schools to exercise this discretion is the Education Law, and the direct basis is often the school's internal rules and regulations (such as the degree qualification documents passed by the school degree committee), which does not constitute a regulatory document in legal theory, Whether the school had the scope provided by laws and regulations for discretion lacks a solid foundation. Looking from another angle, is this the autonomy of the school? In what scope should this autonomy be restricted and should it be subject to judicial review? From the point of view of the law's spirit, the Education Law stipulates the educational responsibilities of schools. In order to facilitate the development of school educational tasks, it stipulates certain internal management rights of the school to students. However, the design and legality of all educational models and systems are stipulated in the Constitution (Nouryan, L. Weisel, M. S.1991, pp-2933). The right to education of citizens is the bottom line and support, and the rights of citizens should be protected and promoted. Students are members of social citizens, not vassals of the education department. This kind of autonomy is quite different from the autonomy of social organizations and enterprises on their members (employees).

\section{LIMITATIONS STIPULATED BY EXISTING LAWS AND REGULATIONS}

So far, there are some laws and regulations governing examinations, mainly the "Regulations on the Management of Students in Regular Colleges and Universities" and the "Measures for Handling Violations of National Education Examinations."The former was formulated in 1990. Article 12 of it stipulates: "Anyone who misses an exam or cheats on an exam without authorization will be counted as zero points for the course and cannot make up the exam normally. If there is indeed a manifestation of repentance, it will be approved by the academic affairs department before graduation. Cheating in the exam shall be subject to disciplinary sanctions", there is no provision for disobeying examination room discipline or cheating on exams.

Since then, examination violations have become serious, and the State Education Commission (Ministry of Education) had frequently issued various notices and declarations, continuously increasing the punishment for cheating in examinations, and setting the precedent for cheating in examinations to expel students. The limitations of these regulations are mostly issued on special matters in a certain period of time. They are time-effective and not universal.

Look at the "Measures for the Handling of Violations of National Education Examinations" (enacted in 2004 and revised in 2012). This administrative regulation only partially solves the problem of cheating in examinations, because the measures stipulate that the enrollment examinations of ordinary and adult colleges and universities, and the national postgraduate students Enrollment examinations, higher education self-study examinations and other "national education examinations" are applicable (Petronicolos, L, (1992, pp 1-6). In general, national education examinations are very different from the daily semester examinations, assessments, and single subject examinations, because the former carries the ability to pass public selection mission of realizing certain political and social functions. This type of examination needs to highlight its authority and impartiality. Violations in national examinations can be described as contempt for authority and have too great a negative impact on the public. However, the importance of daily examinations and the purpose of the examination cannot be compared with them. There is no school-level examination during students' school.

From the content point of view, it distinguishes exam violation and cheating in more detail. Punishment measures include: cancellation of the test score of the subject, the score of each subject registered for the exam at the time is invalid; suspension of the test or delay of graduation. If the test taker obtained by cheating and obtained the corresponding degree certificate, academic certificate, other academic certificate, qualification certificate or admission qualification, the certificate issuing authority shall declare the certificate invalid and order the certificate to be withdrawn or confiscated; he has been admitted or for those who enroll, 
the enrolling school will cancel the enrollment qualification or student status.

\section{THE FOUNDATION OF A HARMONIOUS EDUCATIONAL RELATIONSHIP}

Carrying out educational activities in accordance with the law is the fundamental purpose of education system. Teaching in accordance with the law is not only a behavioral requirement, but also a requirement of documents and regulations issued by the school. Article 33 of the "Measures for Handling Violations of National Education Examinations" stipulates: The handling of violations of the part-time national examination for master's degree studies, the Higher Education Self-study Examination, and other types of education examinations at all levels can refer to these measures(Gomez, K, 2019, pp198-206). This should be a yardstick for formulating and reviewing various school regulations formulated by universities. It can also be further understood that when colleges and universities formulate penalties for students who violate disciplines in examinations, they should not and should not exceed the standards specified in the Measures for Handling Violations of National Education Examinations, otherwise the unity of the educational legal system will be destroyed (Thody, Angela, 1990, pp-59-66).

On the other hand, it is worth noting that both schools and society (such as employers) should work together to eliminate the political identity or negative evaluation of individual performance in the school's disciplinary decision. In China's social value system, the negative impact of "expulsion, dropout, and non-degree granting" is very severe. It is no exaggeration to say that the "death penalty" is imposed on students' future, destiny and social status (Xiao HY, Lian GM, 2004. pp99-104). What we need is a rights society and a harmonious society. Legal education and harmonious education are one of the important subsystems. How the school handles students and whether this handling has good uniformity, credibility, and authority requires rigorous planning, To implement it prudently, and to accept social supervision and judicial review, the unwise method is to make such behaviors administratively legally responsible, to establish the school as an administrative subject with the right to punish and to allow different schools to manage their own affairs. Value is to ensure equal and barrier-free access to education for citizens.

\section{ACKNOWLEDGEMENT}

This research was financially supported by the Theoretical Research Project of Fujian Institute of Petition Theory and Practice (Grant NO.2020-12) .

\section{REFERENCE LIST}

Gomez, K. F (2019). The role of mediation in international commercial disputes: reflections on some technological, ethical and educational challenges. SSRN Electronic Journal.

Hosokawa, S (1978). The educational disputes in postwar days and educational rights. Journal of the Faculty of Education Cultural Science, 29.

Lu BF, Li QR (2005). On the feature of the educational disputes in universities -the resolution of the educational disputes. Journal of Higher Education.

Juan David Piñeres(2011). Approaches to the first debate on bentham in colombia: anthropological conceptions, educational disputes, national aspirations. Revista De Estudios Sociales, 32(39).

Nouryan L, Weisel MS (1991). Bringing mediation to educational disputes. Arbitration Journal, 46(3).

Petronicolos $L$ (1992). Does the u.s. supreme court's recent activism in reviewing educational disputes make the attempt to implement a code of professional ethics for educators a vain effort?. Codes of Ethics, 21.

Thody Angela (1990). Central intervention in local educational disputes: the use of section 68 of the 1944 act. Journal of Educational Administration and History, 22(1).

Xiao HY, Lian GM (2004). On aid system of rights in educational disputes-brief discussion on education arbitration. Journal of Guangxi Administrative Cadre Institute of Politics and Law. 